\title{
A Study on the Cultivation of Values of Maritime College Students' Occupational Pride
}

\author{
Qian Wang
}

\begin{abstract}
In view of the problems that the college students in Maritime major are weak in core values and lack of occupational pride at present,the questionnaire and the form of the symposium have been adopted to investigate the main influencing factors. This paper puts forward the educational countermeasures of constructing the core value system of occupational pride in Maritime College that combining traditional culture with modern occupational knowledge education from the establishment of specialized work institutions, the construction of the campus culture with distinctive maritime characteristics,the strengthening of the construction of the system and culture of Maritime Colleges and Universities, and the guidance of self-development self-education for students.
\end{abstract}

Index Terms-Maritime, undergraduate, occupational pride, values.

\section{INTRODUCTION}

\section{A. Research Background}

The value orientation of contemporary college students is not only related to the future of their own development, but also to the fate of the country and the nation. Maritime college students are a group of distinctive characteristics of college students. Most of them have grown into senior specialized talents in the national shipping industry. As the special talents of the country, the core values of their values are weakened and their occupational pride is not strong enough, and so on should be paid more attention to.

\section{B. The Current Situation of Value Education of Occupational Pride in China}

According to Lan, "the intervention of values and education research in different disciplines makes the studies on the cultivation of values education multidimensional and vivid. At the same time, it also leads to the difficulty of reaching consensus on the basic theory of values education, the ambiguity concept, the difficult establishment of goals and content and so forth, which affects the further development of values education in the field of practice. "

The Maritime Colleges and Universities are developing rapidly and with different levels. How to carry out the education of occupational pride, the core values and build a content system with strong operability is even poorer, and

Manuscript received December 18, 2018; revised April 13, 2019.

Qian Wang is with the Shandong Jiaotong University, China (e-mail: qian_nancy@163.com). there is almost no systematic research.

\section{OVERVIEW OF THE OCCUPATIONAL PRIDE AND RELATED THEORIE}

\section{A. Sense of Pride}

The Chinese Dictionary defines "Pride" as follows: "It is glorious to have a good quality or achieve great achievement by the collective or individual concerned with yourself."

In English, we define "Pride" from two aspects: one refers to the feeling of pleasure or satisfaction when an individual is doing something well. The other is that their views are irrefutable or that someone's achievements are proud, that is, pride, arrogance, etc.

In the field of psychology, Weiner [1] believed that pride is the result of an individual's internal attribution when a positive event occurs. It is an emotion related to the results, which is an early study of the sense of pride in the field of psychological research.

Shorr and McClelland [2] believed that the sense of pride is a happy experience when an individual perceives that their own behavioral results meet the standards or goals of internalization.

Chinese scholars Guo and Wang [3] defined pride as a positive experience produced by individuals when their goals are realized or judged by others.

Du and Xia [4] defined the sense of pride as a positive emotional experience of an individual who attributes a successful event or an active event to the result of his personal ability or effort.

Above all, we find that the sense of pride includes three aspects: achievement, internal attribution and the positive inner experience.

\section{B. Theories of Values Education}

Hofstede believed that values are a general preference for one situation over the other.

Values are the ideas that people embody in the establishment of goals, choice of methods, and the following of rules, which play a guiding role in the behavior of individuals or groups.

Liu [5] held that values education refers to "using the value orientation of humanism to guide the young people to view society and life with the correct value standards, to educate them to see the role of society correctly and to understand the meaning of life, and to correctly understand the value of life."

Lan [6] concerned that the content of values education can be divided into public values education and private values education. The former includes public morality, honesty, science, democracy, collectivism, patriotism and so on, and 
the latter includes aesthetic, love, and career and so on.

Feng [7] put forward several main educational models of values: the model of cognitive development method, the model of social learning method, the model of value clarification method, the model of social action method and so on.

\section{IDEAS AND METHODS OF THE STUDY}

\section{A. Research Ideas}

The survey was conducted on 33 issues, including values awareness, occupational common sense, importance of occupational pride, the relationship between pride and talent, which were related to the growth of students.

\section{B. Research Methods}

Some college students in the College of navigation, Shandong Jiaotong University were investigated by means of anonymous questionnaire survey, as well as symposium and individual talks.

\section{ANALYSIS OF THE VALUES EDUCATION OF OCCUPATIONAL PRIDE}

A total of 100 questionnaires were sent out, and the recovery rate was $100 \%$. Among the questionnaires, $100 \%$ of the effective questionnaires were available. Among the students surveyed, male and female students, student cadres, ordinary students, Party members, as well as excellent students, better students and poor students all accounted for a certain proportion and had certain representativeness. According to the survey and statistical analysis, the results of the questionnaires are close to that of the symposium, which shows that vast majority of the students' answers seriously and the results of the investigation are more credible.

\section{A. Existing Problems}

\section{1) Maritime students' sense of occupational pride is not strong}

$85.2 \%$ students think that occupational pride is not important to the success of person's growth, only $2.3 \%$ students think it important; $75.2 \%$ students think they know about seafarers' knowledge, 5.1\% students know well; $64.3 \%$ students agree that " career success, EQ accounting for 80 percent and IQ 20 percent ",84.4\% students recognize that it is necessary to strengthen the values education of college students' occupational pride. This shows that most students lack sufficient knowledge of the importance of cultivating occupational pride.

\section{2) Maritime students have a strong individual-based thought}

The values of the maritime students are shifting from the traditional social-based thought to the individual-based thought. And many maritime students advocate themselves in their values of life, the subject of individual and the individual struggle.

This problem truly reflects the emergence of the "self" subject of college students.

\section{3) Maritime Students Have Higher Moral Quality and Discipline Values}

When the expression of love is politely declined, 55\% students think that they will be able to stop and face them correctly; $75.87 \%$ students think they have never had cheating; $71.08 \%$ students think they have never absent from the class; $39.25 \%$ students think it is necessary for the teachers to manage the classroom and should take a strict way. It shows that most college students have high moral quality and organizational discipline concept. And they can care about the collective, care for others, unite classmates, respect the teachers, take good care of the public property, be honest and trustworthy, participate in public welfare activities actively, and have a correct outlook on life and values.

TABLE I: THE PROPORTION OF THE OPTIONS

\begin{tabular}{|c|c|c|c|c|c|}
\hline $\begin{array}{l}\text { option } \\
\text { proportion }\end{array}$ & $\begin{array}{c}\text { Filial } \\
\text { piety } \\
\text { of } \\
\text { parents }\end{array}$ & $\begin{array}{l}\text { Study } \\
\text { hard }\end{array}$ & $\begin{array}{l}\text { Observe } \\
\text { law and } \\
\text { discipline }\end{array}$ & $\begin{array}{l}\text { Contribute } \\
\text { to the } \\
\text { collective }\end{array}$ & $\begin{array}{l}\text { Civic } \\
\text { minded }\end{array}$ \\
\hline $\begin{array}{l}\text { What do you } \\
\text { think is the main } \\
\text { performance of } \\
\text { College }\end{array}$ & & & & & \\
\hline $\begin{array}{l}\text { Students' sense } \\
\text { of } \\
\text { responsibility? } \\
\text { (3 items } \\
\text { Limited) }\end{array}$ & $79.5 \%$ & $41.5 \%$ & $35.2 \%$ & $28.0 \%$ & $29.2 \%$ \\
\hline
\end{tabular}

\section{B. Analysis of the Reason for Problems}

\section{1) Lacking the recognition of maritime college students' occupational pride education}

Seafarers have their own occupational characteristics, such as working with responsibility, perseverance, consideration; paying attention to deal with problems with strong, objective and independent attitude; having firm indomitable quality, teamwork spirit and so on. To strengthen these excellent qualities, we should strengthen the education of "occupational pride", let college students take pride in the career of the future seaman, and work hard to cultivate good character.

2) The realization of value is becoming more and more economical, which is unstable to the future employment thought

Maritime majors belong to one of nine kinds of special and tough industries. Most of them come from rural areas or poor families. With the increasingly marketization of the social employed mechanism, part of maritime college students often only consider whether they are engaged in simple and easy work or the amount of income after employment and so on. But the understanding of the career ideals of the shipping industry is relatively vague. Therefore, their occupational ideas become unstable, and they want to change their original intentions and abandon careers in navigation or job-hopping

\section{3) Maritime College students are misplaced in their}


values, and lack of occupational ethics consciousness, and they attach more importance to the study of occupational skills

Compared with other majors, the quality of maritime graduates has its special advantages, and it is outstanding in many aspects. At the same time, however, which has a great deal to do with the biased understanding of the occupational ethics concept during the study period. It shows that they have not recognized the importance of fostering occupational ethics fundamentally.

\section{COUNTERMEASURES AND SugGESTIONS}

\section{A. Building a Core Values System of Occupational Pride in Maritime College Which Combines Traditional Culture with Modern Occupational Knowledge Education}

The construction of the core values system of "occupational pride" plays an important role in the maritime college students' successful completion of their studies, employment placement and prediction of life achievements. Using the concept of "people-oriented" to cultivate talents, maritime college should set up the core values of nautical culture and maritime culture, focus on shaping the strength of faith, moral strength and psychological strength, nurture and guide the maritime students to consciously form a sense of pride, honor and values of navigation, and fully mobilize students' enthusiasm to study. Thus, makes them love and devote to the voyage.

\section{B. Concreting a Specific Implementation Plan for the Content System of "Occupational Pride" in Maritime College}

\section{1) Set up a special working institution}

In order to ensure the effective implementation of the values education of "occupational pride", we can set up special values education department and offer relevant life outlook and methodology courses. At the same time, in order to give full play to the students' self - management, self education, and self - growth enthusiasm, we can form the students' organization to cultivate "occupational pride", to create a good atmosphere for the values education and guide the students.

\section{2) Construct campus culture with distinctive maritime features}

The nautical campus culture is the sum of the material culture and spiritual culture, which is created by all of the teachers and students in the school. It has extensive appeal and attraction. It is a very easy carrier for students to accept. It has double effect with half effort to mould the personality of students and to cultivate the quality of students. The spiritual culture construction of maritime college is the core content of campus culture construction and the highest level of campus culture. The construction of campus culture with distinctive maritime features will help maritime college students to cultivate their sentiment, shape their beautiful mind and stimulate their pioneering spirit.

3) Strengthen the construction of the institutional culture of maritime colleges and universities
Because of the particularity of maritime college, the construction of institutional culture is also crucial. Practice has proved that the implementation of semi-military management to maritime students has achieved good results in training seafarers' quality.

In the booming development of the shipping industry, in order to promote the formation of correct values for maritime college students, and to cultivate high-quality shipping talents which are more in line with the requirements of the times and have more international competitiveness. Thus, it is suggested that the semi-military management of the maritime college students should gradually transfer to the paramilitary management. This is a way of exploring students' management, and is also the cultivation of students' quality. The aim is to cultivate the students' self-conscious behavior with the strict discipline of the army, and to cultivate the students' team consciousness with the unity spirit of the army, so that the students can set up a good study attitude, develop good study atmosphere, and possess the good quality and independent personality of the future navigational profession.

\section{4) Guide students' self-education}

Self-education of "occupational pride" can be carried out from aspects of self-knowledge, self-education, self-management, self-development and so on. We should pay attention to guiding students to reflect on their future career so that students can recognize the advantages and disadvantages of their own values in time promote their strengths and circumvent their weaknesses and make continuous progress. To realize self-education, ask students to correctly face the changes in their emotions, learn to manage their emotions, clear up obstacles in the process of growth and display personal advantages. The realization of self-management requires that students can correctly evaluate themselves, keep learning, cognition and adjustment, realize self-development, and develop their values in a positive direction.

\section{CONCLUSION}

In a word, based on the overall development of the shipping industry, the values education of occupational pride of maritime college students is not only beneficial to the strength of self-respect and the motivation of individual, but also to the individual's investment in social behavior. It can help nautical students understand themselves correctly. Through the combination of semi-military management, it can stimulate the enthusiasm of students' patriotism, develop the vocational quality education of navigation, values education, train high-quality shipping talents and promote the improvement of the quality of the maritime college students jointly.

\section{REFERENCES:}

[1] B.Weiner, "An attribution theory of achievement motivation and emotion," Psychological Review, 1985, vol. 92, pp. 548-573.

[2] D. N. Shorr and S. E. McClelland, "Children's recognition of pride and guilt as a result of helping and not helping child study journa," vol. 28 pp. $123-135,1998$ 
[3] X. Y. Guo and Z. H. Wang, "The concept, function and significance of positive emotion [J]," Psychological Science Progress, 2007, vol. 15, pp. 810-815

[4] J. Z. Du and B. L. Xia, "Proud structure, measurement, expression and recognition" Psychological Science Progress, 2009, vol. 17, no. 4, pp. 857-862.

[5] J. L. Liu, Values Education, Beijing: Educational Science Press, 2007.

[6] J. F. Lan, "Values education under the background of value diversification," presented at the 21st Century Values Education and the Academic Symposium on Cultural Strategies, 2001.
[7] Z. J. Feng, "Kolberg's view on the construction of moral cognitive development," Studies in Foreign Education, 1993, vol. 2.

Qian Wang was born in 1981 in Weihai city of Shandong province of China and graduated from Dalian Maritime University with a master's degree in international law in 2003. Now she was a lecture of navigation college of Shandong Jiaotong University, engaged in the research of navigational education and maritime law. 